\title{
BİR HAC EL KİTABI ÖRNEĞİ "HACILARA YÂDİGÂR”
}

\author{
A Handbook Named Hacilara Yadigar
}

\author{
Bilge Karga GÖLLÜ1
}

\author{
Makale Bilgileri
}

Geliş Tarihi : 01.10.2020

Kabul Tarihi : 11.11.2020

Yayın Tarihi : 22.06.2021

\section{Özet}

Her dinin kendine özgü kutsal mekânlar vardır. Bu yerlerin ziyaret edilmesinin kişiye ebedî bir hayat kazandıracağına inanılmıştır. Bundan dolayı hac yollarındaki her türlü zorluk göze alınmış, hac kafileleri yılın belli dönemlerinde ibadetini gerçekleştirmek için bu yolculuklara çıkmıştır. Çoğunlukla geçmişteki ulaşım imkânlarının sinırlı olmasıyla bağlantılı olan bu sorunlar, günümüzde gelişen teknolojiyle birlikte değişmiş, çoğunlukla giderilmiştir. Şimdilerde hact adayları ziyaretlerini daha kolay yapabilmektedirler.

İslâm dininde haccın gerçekleştirildiği Mekke ile Medine Müslümanların yüzyıllardır bütün zorlukları göze alarak gitmek istediği en önemli şehirlerdir. Bu kutsal şehirlerle birlikte önemli zâtların ve mekânların ziyaret edilmesi ise hac güzergâhlarını önemli kılmıştır. Menâzil-i hac türündeki eserler, tarih boyunca izlenilen yollar hakkında önemli bilgiler vermektedirler. Bunun dışında haccın edâsını (menâsik) içeren ve hacca dair diğer eserler de geçmişin hac anlayış ve yolculuğuna ışık tutmaktadır.

İçeriklerine ve yazllış amaçlarina göre dört grupta toplanabilen (Hac el kitaplar, rehber nitelikli hac seyahatnameleri, hatıra ve rapor nitelikli hac seyahatnameleri, edebî hac seyahatnameleri) hacca dair eserler arasında en fazla edebî hac seyahatnâmeleri üzerinde araştırmalar yapıldiğı görülmektedir. Hac el kitapları ise pratik bilgiler verme amacıyla yazıldığından şimdiye kadar üzerinde pek fazla durulmamiştır. Hâlbuki bu tür eserlerde tarihe ve kültüre yönelik pek çok unsura rastlamak mümkündür. Hac el kitaplarında haccın nasıl eda edileceği ön planda olsa da güzergâhlar, ziyaret yerleri, ulaşım vb. döneme ait bilgiler bulunmaktadır. Aynca halka hitap eden bu eserlerdeki dil ve anlatımın dönemlere göre gösterdiği değişim araştırılması gereken başka bir konudur. Bu doğrultuda, çalışmamızda Hacılara Yâdigâr isimli matbu eserin tanıtım ve değerlendirilmesi amaçlanmıştır.

12 sayfadan oluşan Hacılara Yâdigâr isimli eserin kapağına "Hacılara Yâdigâr Mekke-i Mükerreme Medîne-i Münevvere Cidde Kuds-i Şerîf Şâm-ı Şerîf ve Surre-i Hümâyûn Manzaraları" yazılmış olup sayfalar 3 sütuna ayrılmıştır. Fotoğrafların da yer aldığı bu el kitabının biçim, içerik, dil ve anlatım olarak değerlendirilmesiyle dönemin hac ibadetinin nasıl gerçekleştirildiği, nelere dikkat edildiği, yolculukta hangi vasıtaların kullanıldığı, hacılara ne gibi önerilerde bulunulduğu, güzergâh boyunca nerelerin ziyaret edildiği tespit edilmeye çalışılmıştır. Ayrıca yapılan bu çalışmayla, günümüzdeki hac el kitaplarının XX. yüzyılın başlarında yazıldığı tahmin edilen bir örneği sunulmuştur. Bu tür eserlerin hazırlanışında yüzyıllara göre oluşan değişimlerin nasıl bir seyir izlediği ise ayrı bir araştırmanın konusu olup hac el kitapları hakkında toplu değerlendirmelerin yapılmasını gerektirmektedir.

Anahtar Kelimeler: Hac • El Kitabı • Kutsal Şehir ve Mekânlar.

\footnotetext{
1 Arş. Gör. Dr., Çukurova Üniversitesi/Fen-Edebiyat Fakültesi/Türk Dili ve Edebiyatı Bölümü/Eski Türk Edebiyat1 Anabilim Dal, bilgekarga2011@gmail.com, https://orcid.org/0000-0002-6786-3842
} 


\section{Giriş}

İslâm'in şartlarından biri olan haccın, anlamıla ilgili kaynaklarda şu bilgilere rastlanmaktadır: "Zil-hicce ayında Mekke-i Mükerreme'de menâsik ü merâsim-i mu'tâde ile Ka'be-i şerîfeyi ziyâret ve tavâf etmek resmi ki şerâiit-i hamse-i İslâm'dandır" (Şemseddin Sami, 2006, s. 540); "Mebnâ-yı İslâm olan erkân-1 hamseden biri bulunan farizayı eda için Mekke-i Mükerreme'ye gitmek" (Muallim Nâcî, 2009, s. 183); Mekke'de belirgin vakitlerde Allah'ın evini ziyaret etme (Enverî, 1312, s. 842); “... fikıh terimi olarak imkânı olan her Müslüman'ın belirlenmiş zaman içinde Kâbe'yi, Arafat, Müzdelife ve Mina'yı ziyaret etmek suretiyle yaptığı ibadet..." (Harman, 1996, s. 382).

İslâmî kaynaklarda haccın geçmişi $\mathrm{Hz}$. Âdem'e kadar uzanır. Bazı rivayetlere göre Kâbe'yi önce melekler tavaf etmiş, sonra da Hz. Âdem Mekke'ye giderek Arafat'ta Hz. Havvâ ile buluşup Beytullâh'n etrafindaki hacla ilgili kutsal yerleri gösteren melek eşliğinde haccetmiştir. Nuh tufanının ardından kumlar altında kalan Kâbe, Hz. İbrâhîm ve oğlu Hz. İsmâil tarafından temelleri gözetilerek ${ }^{1}$ tekrar yapılmıştır. Hac yapmak üzere insanları Mekke'ye davet eden ilk peygamberin ise $\mathrm{Hz}$. İbrâhîm olduğu bilinmektedir ${ }^{2}$. Hz. İbrâhîm haccın menâsikini tespit ederek Kâbe'nin her yıl ziyaret edilmesini sağlamış, sonra gelen peygamberler ve onların ümmetleri de Kâbe'yi ziyaret etmişlerdir. İslâm'in doğuşu sırasında Kâbe'yi tavaf, umre, Arafat ve Müzdelife'de vakfe, kurban kesme gibi âdetler devam ettirilmekte, hac putperest gelenekleriyle birlikte sürdürülmekteydi (Özaydın, 1996, s. 386388).

\section{Hac Kitaplar1}

Kutsal topraklar, her dönemde insanlığın dikkatini çekmiştir. Dinin emrettikleri haccın nasıl yapılması gerektiğiyle ilgili endişelerin, ulaşım imkânları ise yolculuklarda karşılaşılan zorlukların belirleyicisi olmuştur. Bu noktada hacla ilgili yazılan eserlerin ayrı bir yeri vardır. Hacca dair eserler "içeriklerine ve yazılış amaçlarına göre dört grupta toplanabilir: (I) hac el kitaplar1; (II) rehber nitelikli hac seyahatnameleri; (III) hatıra ve rapor nitelikli hac seyahatnameleri; (IV) edebî hac seyahatnameleri" (Coşkun, 2002, s. 6).

Şimdiye kadar üzerinde herhangi bir çalışma yapılmamış ${ }^{3}$ olan Hacılara Yâdigâr isimli eser ise fotoğraflı olup hacıların memleketlerinden ayrılışından haccı tamamlayana kadar yapmaları gerekenlerle ilgili onlara pratik bilgiler sunmaktadır. Ulaşım sırasında hangi vasıtaların kullanılacağı hakkında yolculuk zahmetlerini hafifletecek önerilere yer veren eser, hac yolculuğu sırasında mutlaka ziyaret edilmesi gereken mekânlara da işaret etmektedir. Bu yönüyle eser, hem hac konakları (menâzil) hem de haccın edasındaki kuralları (menâsik) anlatan ve hazır bilgi vermeyi hedefleyen hac el kitapları arasında değerlendirilebilir. Kişisel

\footnotetext{
1 bk.: Bakara 2/127: "Ve ne vakit ki İbrahim, Beyt'in temellerini yükseltmeye başladı, İsmail ile birlikte şöyle dua ettiler; Ey Rabbimiz, bizden kabul buyur, hiç šüphesiz ișiten sensin, bilen sensin”.

2 bk.: Hacc 22/27: "İnsanları hacca çağır, yürüyerek veya incelmiş binekler üstünde (uzak yollardan) her derin vadiyi aşarak sana gelsinler".

${ }^{3}$ Araştırma konumuz olan Hacılara Yâdigâr adlı eser, şu çalışmada Şam tarihine dair eserler arasında gösterilmiştir: Cengiz, O. (2018). Şam tarihine dair bir bibliyografya denemesi. Türk Akademik Araştırmalar Dergisi Uluslararası Multidisipliner Kongresi, Antalya.
} 
olmayan bir anlatıma sahip olması; yazarının veya kâtibinin adını, yazıldığı tarihi içermemesi (Coşkun, 2002, s. 6) de Hacılara Yâdigâr adlı eserin hac el kitapları arasında değerlendirilmesini gerektirmektedir.

Yazma eser kütüphanelerinde, yıpranma ve yırtılma gibi sebeplerle çoğu yok olmuş olsa da hacılara yol gösterme amaçlı yazılmış bu tür birçok kitapçık bulunmaktadır. Bu eserler genellikle aynı bilgileri farklı şekillerde anlatmaktadırlar (Coşkun, 2002, s. 7). Örneklerinin fazla olması ve birbirini tekrar etmesi nedeniyle de metin çeviri ve incelemelerine pek ilgi gösterilmediği, konuyla ilgili çalışmaların edebî değeri olan eserlere yönelik olduğu dikkat çekmektedir ${ }^{4}$.

Hac el kitapları hakkında herhangi bir çalışma yapılmadığı gibi Hac Seyahatnâmeleri üzerinde duran kapsamlı bir çalışmada da hac el kitapları konu dışında bırakılmıştır ${ }^{5}$. Oysa hacılara yol gösterme amacıyla hazırlanan hac el kitaplarına örnek olan bu eserler, tarihe 1şık tutmaktadırlar. XX. yüzyılın başlarındaki hac edasına dair faydalı bilgi ve fotoğraflarla dönemin hac ibadetini yansitan Hacılara Yâdigâr isimli el kitabı da böyle bir eserdir. Bu çalışmayla, günümüzde Diyanet İşleri Başkanlığı tarafından organize edilen hac yolculuklarının eskiden ne şekilde gerçekleştiği gözlenmiş, bugün de basılan el kitaplarının eski bir örneği sunulmuştur.

\section{Hacılara Yâdigâr'ın Biçimsel Özellikleri}

Matbu olan Hacılara Yâdigâr isimli kitapçık, İ.B.B. Atatürk kitaplığında bulunmaktadır ${ }^{6}$. Kütüphanede bulunan eserler birbirinin kopyası durumundadır ${ }^{7}$. İkisinde de aynı kelimelerde hatalı yazımlar vardır. Çalışmaya esas alınan eser (Bel_Osm_B. 00349) kapak hariç 12 sayfa ve $23 \times 32 \mathrm{~cm}$. ölçülerinde olup eserde rutubet lekeleri mevcuttur. Diğeri

\footnotetext{
${ }^{4}$ Mazıŏlu, H. (1974). Ahmed Fakih Kitâbu Evsâfi Mesâcidi's-Serîfe. Ankara: Türk Dil Kurumu Yayınları; Coşkun, M. (2002). Manzum ve mensur Osmanlı hac seyahatnameleri ve Nâbî'nin Tuhfetü'l-Harameyn'i. Ankara: Kültür Bakanlığı Yayınları; Aksoyak, İ. H. (2020). Nâtık Mehmed Efendi Tuhfe-i Nâtık. İstanbul: KTB; Aksoyak, İ. H. (2012). Nâbî'nin Tuhfetü'l-Harameyn'inin Edirneli Nâtık'ın Tuhfetü'l-Haremeyn'ine etkisi: hikâyeler, gelenekler, inanışlar... Milli Folklor, 24 (95), 9-22; Süer, F. R. (2015). Umdetü'l-hüccâc. Sivas Belediyesi; Nalçacigil Çopur, E. (2017). Gubârînnin eserlerinde hac ibadeti. Türk İslâm Medeniyeti Akademik Araştırmalar Dergisi. 12 (23), 191-211; Weyso, M. (2011). Hac yolculuğu metinleri bağlamında 17. yüzyıl halk osmanlıcası. Yüksek Lisans Tezi, İstanbul Kültür Üniversitesi; Donuk, S. (2017). Servet mahlaslı bir şaire mâl edilen manzum Hac seyâhatnâmesi. SUTAD, (41), 1338; Kiraz, S. (2020). Fethî'nin manzum Menâzil-i Hacc'1. RumeliDE Dil ve Edebiyat Araştırmalar Dergisi. (18), 310334; Gül, Â. (2006). Abdurrahman Gubârî'nin hayat1 ve eserleri ve Menâsik-i Hac adlı eseri (edisyon kritik). Yüksek Lisans Tezi, Marmara Üniversitesi; Hazırbulan, T. (2017). Anonim bir yolculuğun durak noktaları: Menâzil-i Gökbuze ve Menâzil-i Hersek Ma' Derbend-i Yeni Köy. Çoban Mustafa Paşa ve Kocaeli Tarihi ve Kültürü Sempozyumu IV, Kocaeli. 1957-1973; Koyuncu, F. (2017). Cûdî'nin manzum hac seyahatnâmesi. Littera Turca, 3 (1), 177-219; Kararmaz, S. (2019). Seyahatnâmeler ışığında Mekke'de Osmanlı mîmârî eserleri. Yüksek Lisans Tezi, Fatih Sultan Mehmet Vakıf Üniversitesi; Karataş, A. (2012). Nâlî Mehmed Efendi'nin Menâsik-i Hac manzumeleri. M.Ü. İlahiyat Fakültesi Dergisi, 42 (1), 77-94; Donuk, S. (2017). Sulhî'nin manzum hac menâzilnâmesi. Divan Edebiyatı Araștırmalar Dergisi 18, 85-118; Kiraz, S. (2020). Konyalı Seyyid Mehmed Efendi'nin manzum Menâsik-i Hacc'1. Külliyat Osmanlı Araştırmalar Dergisi 10, 1-21; Ramazanoğlu Özcan, N. (2011). Seyyid İbrahim Hanîf'in hayat, eserleri ve Hâsıl-ı Hacc-ı Şerîf Li-Menâzili'l-Haremeyn adlı eserin incelenmesi. Yüksek Lisans Tezi, Ankara Üniversitesi, Ankara; Karataş, A. (2003). Türk İslam edebiyatında manzum Menâsik-i Haclar ve Nâlî Mehmed Efendi’nin Menâsik-i Hac adlı eseri. Yüksek Lisans Tezi, Marmara Üniversitesi, İstanbul; Çavuşoğlu, R. (2019). Hicaz yollarında bir sûfî Mehmed İlhâmî'nin hac seyahatnâmesi. İstanbul: Okurakademi; Kiraz, S. (2020). İndî’nin manzum Menâsik-i Hacc'ı (İnceleme-Metin Dizin ve Sözlük). Erzurum: Fenomen.

5 Coskun, M. (2002). Manzum ve mensur hac seyahatnameleri ve Nâbî'nin Tuhfetül-Harameyn'i. Ankara: Kültür Bakanlığ Yayınları, s. 7.

${ }^{6}$ Hacılara Yâdigâr'a dair herhangi bir bilgiye şu eserde rastlanmamıştır: Türkiye Basmalar Toplu Kataloğu Arap Harfli Türkçe Eserler (1729-1928). (1990). haz.: Müjgan Cunbur-Dursun Kaya. C. I. Ankara: Milli Kütüphane.

7 bk.: http:/ / ataturkkitapligi.ibb.gov.tr/yordambt/yordam.php?sayfaOturumAc Erişim: 20.07.2020/12:22.

$8 \mathrm{Bu}$ yazım hataları çalışmanın metin kısmında belirtilmiştir.
} 
ise (Alb_000235) kapak hariç 11 sayfadır. Eser, $24,5 \times 34 \mathrm{~cm}$. ölçülerinde olup kütüphane kayıtlarında eserin bordo deri mahfaza içinde ve karton kapaklı olduğu belirtilmiştir. Rutubet lekeleri yoktur.

Eserin" kapak sayfasında "Hacılara Yâdigâr Mekke-i Mükerreme Medîne-i Münevvere Cidde Kuds-i Şerîf Şâm-1 Şerîf ve Surre-i Hümâyûn Manzaraları” yazmaktadır. Başlığın altına "Bilâd-1 mübârekenin menâzır-1 'âliyesiyle müzeyyen olan şu mecmû'a hüccâc-1 kirâma lâzım pek çok ma'lûmâtı câmi'dir" notu düşülmüştür. Ayrıca eserin Türk matbaacılığında önemli bir yeri olan ${ }^{10}$ Ahmed İhsan Matbaas11'nda basılmış olması yayının II. Abdülhamid (18421918) döneminde gerçekleştiğini göstermesi bakımından önemlidir. Ayrıca bu matbaa II. Abdülhamid'in takdirini de kazanmıştır (Ebüzziya, 1989, C. 2, s. 95). Esere, 6907 numaras1 verilmiş ${ }^{12}$, sayfa numarası ise yazılmamıştır. Eserin iki sayfası 3 sütuna ayrılmış yazılardan ve fotoğraflardan meydana gelmiştir. Fotoğrafların altındaki açıklamalar ise hem Türkçe hem Arapça cümle kuruluşuyla iki türlü kaydedilmiştir.

\section{Hacılara Yâdigâr'ın İçerik Özellikleri}

Eserde şu alt başliklara yer verilmiştir: "Önce Mekke'ye mi yoksa Medîne'ye mi gitmelidir?", "Hicâz’a gitmeden evvel”, "Deniz Yolu”, "Mısrül-kâhirde Ziyâret Yerleri”, "Mîkât”, "İhrâmda mubâhlar", "Cidde'de", "Mekke'de".

Eserin kapağındaki başl1kta yer almasına rağmen Surre-i Hümâyûn Manzaraları, Şâm1 Şerîf, Kuds-i Şerîf ve Medîne-i Münevvere'ye ayrı bir başlık açılmamıştır. Bu yerlerden Kudsi Şerîf ve Medîne-i Münevvere'ye dair bilgilere diğer alt başlıklarda yer verilirken, Şâm-1 şerîf ve surre-i hümâyûn ${ }^{13}$ manzaraları fotoğraflarla örneklendirilmiştir.

\section{1. Önce Mekke'ye mi yoksa Medîne'ye mi gitmelidir?}

Hacıların öncelikli olarak Mekke ve Medine'den hangisine yönelmesi gerektiği âlimlerin görüşlerinden yararlanılarak sunulmuştur. Alkame, Esved, Ömer bin Meymûn ve Semerkandî'nin ilk olarak Medîne'ye gidilmesi gerektiği yönündeki görüşleriyle Ebû Hanîfe'nin önce Mekke'ye, Arafat'tan sonra Medîne'ye gidilmesini uygun bulan düşüncelerine yer verilmiştir.

Mekke-Medîne arası yolculuğun zamanı ulaşımın hangi vasıtalarla yapılacağına bağlanmıştır. Hacdan dönerken deniz yolunu tercih edeceklerin iki bayram arasında, kara yoluna başvuracakların Arafat'tan sonra Mekke'den Medine'ye gitmesi gerektiği ifade

\footnotetext{
9 Çalışmanın metin kısmında Bel_Osm_B. 00349 numaradaki matbu eser esas alınmıştır.

10 Geniş bilgi için bk.: Rukancı, F. ve Anameriç H. (2009). Türk matbaacılı̆̆ının önemli isimlerinden Ahmed İhsan (Tokgöz) ve matbaası. Erdem 54, 149-188.

11 Ahmed İhsan Tokgöz (1867-1942) tarafindan kurulan ve sirasıyla Âlem Matbaası Ahmed İhsan ve Şürekâsı (1890), Ahmed İhsan Matbaası ve Şürekâsı, Matbaa-i İhsan, Ahmed İhsan ve Şürekâsı Matbaacılık Osmanlı Şirketi, Matbaa-i Ahmed İhsan ve Şürekâsı unvanlarını alan yayınevi (Ebüzziya 1989, C. 2, s. 94).

12 Diğer kopyada 235 yazmaktadır.

13 Hac döneminden önce Mekke ve Medine halkına dağıtılmak için yollanan para, altın ve diğer eşyalar anlamına gelmektedir. Abbâsi halifesi Mehdî-Billâh zamanında (775-785) surre gönderilmeye başlandığı düşünülmektedir. Osmanlılar döneminde ise Haremeyn'e ilk surenin ne zaman gönderildiği bilinmemekle birlikte yaygın rivayete göre Çelebi Sultan Mehmed (1413-1421) surre gönderen ilk Osmanlı sultanıdır. Haremeyn'e surre gönderme geleneği XIX. yüzyılın başlarında Mekke ve Medine'nin Vehhâbiler’in yönetiminde kaldığı yıllar haricinde 1915 y1lına kadar kesintisiz devam etmiştir (Buzpinar 2009, C. 37, s. 567-568).
} 
edilmiştir. Ancak bu noktada eski ulaşım sistemiyle (gidiş deniz yoluyla, dönüş kara yoluyla) yeni olanaklar karşılaştırılmış ve artık demir yolları olduğundan bu vasıtanın gidip dönmek için daha elverişli olduğuna işaret edilmiştir.

\subsection{Hicâz'a Gitmeden Evvel}

$\mathrm{Bu}$ başlık altında hacıların evlerinden çıkmadan önce yapması gerekenler aktarılmıştır. Hacıların ilk dikkat edeceği husus ise ölümü akıldan çıkarmamaktır. Alışveriş yaptığı kişilerle, evladı, karısı, akrabaları ve düşmanlarıyla helalleşmeli ve ailesine yetecek yiyecek, içecek, giyecek temin etmelidir. Daha sonra da 2 rekât nâfile namazı kılarak selametle gidip gelmesi için Allah'a yalvarıp evinden çıkmalıdır.

\subsection{Deniz Yolu}

Hicaz’a deniz yoluyla gitmek isteyenler için ilk olarak İskenderiye’ye çıkılması gerektiği belirtilmiştir. Hicaz’a doğrudan bilet alınırsa Süveyş yolunun kullanılmasıyla hacılar için zorlukların oluşacağı ifade edilmiştir. Hicaz’a doğrudan bilet alan hacıların oradan Cidde'ye gideceği ve vapuru ${ }^{14}$ günlerce beklemek mecburiyetinde kalacağı söylenmiştir. İskenderiye'den Süveyş'e ise demir yoluyla gidilmesi önerilmiştir.

Bilindiği gibi ilk demir yolu 1825'te İngiltere'de inşa edilmiştir. Fransa'da 1832'de, Almanya'da ise 1835 'te trenler yolculara hizmet vermeye başlamıştır. Gittikçe gelişen bu ulaşım sistemine karşı Osmanlı imparatorluğunda da hayranlık uyanmıştır. Abdülmecid'in bu konuda çeşitli girişimleri olmuştur. Ancak demiryolu inşasına dair bilgi ve sermaye yetersizliği gibi önemli problemlerle karşılaşılmıştır. Bu sebeple Avrupalı sermaye sahiplerine imtiyazlar vermek zorunda kalınmıştır. İlk demiryolu projesi olan Köstence-Çernavoda hattı 4 Ekim 1860'ta açılmıştır. İzmir-Aydın hattının inşası ise Abdülmecid döneminden sonraya kalmıştır (Karal, 1988, C. VI, s. 263-264). Maddi ve manevi birçok kolaylık sunan demiryollarıyla ilgili en büyük gelişmeler ise II. Abdülhamid ${ }^{15}$ döneminde yaşanmıştır. "Bu devre bir isim vermek lâzım gelirse, tereddütsüz denebilir ki onun devri demiryolları inşa ettirip işletmek devridir" (Karal, 1988, C. VIII, s. 468). II. Abdülhamid’in en önem verdiği hat ise Hicaz demiryollarına aittir. 1901 yılında yapımına başlanan bu demiryolu hatt1 1500 kilometre uzunluğunda olup Eylül 1908'de Medine'ye ulaşmış ve Şam'ı Medine'ye, Havran'1 da Der'a'ya Hayfa yoluyla denize bağlamıştır (Karal, 1988, C. VIII, s. 471). Eserde ise İskenderiye-Süveyş arasının demiryoluyla gidilmesi önerildiğinden henüz Hicaz demiryollarının tamamlanmadığı anlaşılmaktadır. Eserdeki misafirhane fotoğrafı da 1901 sonrasını işaret etmektedir. Çünkü hacıların dinlenebilmesi için inşa edilen misafirhane ${ }^{16} \mathrm{H}$. 1318 Zilhicce'sinde (Nisan 1901) açılmıştır (Kararmaz, 2019, s. 134). Bu nedenle hac el

\footnotetext{
14 1900'lü yıllarda buharlı gemiler nehir taşımacılığında adeta devrim yapmıştır (Göçer, 2016, s. 153).

15 II. Abdülhamid dönemindeki hac yolculukları hakkında geniş bilgi için bk.: Sarıyıldız G. ve Kavak A. (2009). Halife II. Abdülhamid'in hac siyaseti Dr. M. Şakir Bey'in Hicaz hatıralar. İstanbul: Timaş.

16 Geniş bilgi için bk.: Sarıyıldız, G. (1994). II. Abdülhamid’in fakir hacılar için Mekke'de inşa ettirdiği misafirhâne. Tarih Enstitüsü Dergisi, 14, 121-145.
} 
kitabının basım tarihini Nisan 1901 ile Hicaz demiryollarının hizmete açıldığ 1908 yılları arasına tarihlendirmek mümkündür.

Bu başlıktaki ikinci öneri ise doğrudan Cidde'ye bilet alınmayıp İskenderiye'ye kadar gitmek ve oradan deniz yoluyla Süveyş'e varmak şeklindedir. Süveyş’ten bir vapurla Cidde'ye gitmek hacılara vakit kazandıran daha kolay bir yol olarak gösterilmiştir. Bu önerilerde hacıların hem maddi imkânlarını gözetmek hem de zamandan tasarruf etmek amaçlanmıştır: "Hâl bu ki doğrudan doğruya Cidde'ye kadar bilet almayıp da İskenderiyye'ye çıkılır ve oradan teymur yoluyla Süveyş'e gidilirse oradan ilk hareket edecek vapurun acentesinden bir bilet alınip vakt gầib etmeksizin sühûletle Cidde'ye vâsıl olunur”.

Kahire'den sonra Misır'n ve bütün Afrika kıtasının en büyük şehri olan (Şemsettin Sâmi, 1996, C. 2, s. 931) İskenderiye, vasıta değiştirmek için bir durak olmanın yanında ziyaret edilmesi gereken önemli bir yer olarak da vurgulanmıştır. Sadece şehrin ulaşım kolaylığının değil, ziyaret bölgesi olma özelliğinin de göz önünde bulundurulması istenmiştir. $\mathrm{Bu}$ durum eserde şöyle dile getirilmiştir: "İskenderiyye tarîkinde bir fâ'ide daha vardır. Bir kerre ba'z-ı zevât-ı şerîfenin kabrleri ziyâret olunur; bir de Mısr gibi bir ma'mûre-i İslâmiyye'nin ziyâret ü müşâhedesiyle temettu' olunur. İskenderiyye'de bulunan başlıca makâbir-i 'âliyye şu zevât-ı muhteremenindir: Zü'l-karneyn ve Danyâl 'aleyhi's-selâmın ve ashâb-ı kirâmdan 'Abdü'r-rezzâk radiya'llâhu 'anh hazretlerinin ve Seyyid 'Abdullâh el-Magribî ve tarîk-i Şâzeliyye a'zâsindan Ebû'l-‘abbâs ve Kâfiye sâhibi İbn-i Hâcib hazretlerinin merâkıd-ı şerîfeleri”

\subsection{M1srü'1-kâhirde Ziyâret Yerleri}

İskenderiye'de ziyaret edilmesi gereken mekânlardan sonra Mısır'in en önemli şehri Kâhire'deki ziyaret yerlerinden bahsedilmiştir. Uğrayanları manevi yönden rahatlatacağı belirtilen mekânların başında Haseneyn camisinde gömülü Kerbelâ şehidi İmâm-1 Hüseyn hazretlerinin mezarı ve İdrisü'ş-Şâfi'nin mezarı gelmektedir. Bunların dışında da pek çok bölge ve kutsal mezarın burada bulunduğu söylenmiştir.

\subsection{Mîkât}

"Mekke'de hacıların ihrâma büründükleri yerin adı" (Parlatır, 2010, s. 1092) anlamına gelen "mîkât" başlığında deniz yolunu tercih edenlerin Şâb denizinde17 Medîne-i Münevvere'nin iskelesi olan Yenbu ${ }^{18}$ 'dan sonra Râbig19 dağı hizasında ihrama girdikleri anlatılmıştır. Karadan gidenlerin ise Mekke-i Mükerreme mîkâtı sınırında ${ }^{20}$ ihrama girdikleri söylenmiştir.

İhrâma girecek olanların yapması gerekenler şöyle sıralanmıştır: gusl etmek, koltuk ve avret yerlerini temizlemek, tıraş olmak, tırnaklarını kesmek. Daha sonra iki rekât namaz kılan

\footnotetext{
17 Kizıldeniz'e verilen isim (Şemsettin Sâmi, C. 4, 1996, s. 2803).

18 Medine'ye yaklaşık $200 \mathrm{~km}$. uzaklıkta bulunan ve Suriye-Yemen ticaret güzergâhında yer alan liman şehridir (Bilge, Küçükașçı, C. 43, 2013, s. 421).

${ }^{19}$ Mekke’ye $186 \mathrm{~km}$. uzaklıkta olan şehir doğrudan Mekke’ye giden hacıların uğrak yeridir (Öğüt, C. 30, 2005, s. 48).

20 Geniş bilgi için bk.: Öğüt, S. (2005). Mîkât. DİA, 30: 48-49, İstanbul: TDV.
} 
hacıların okuması gereken bazı dualara işaret edilmiş, duadan sonra ise hacıların elbiselerini ç1karıp ihrama girmeleri istenmiştir.

İhrâmın iki parça beyaz havludan ibaret olduğu söylenerek yapılacak faaliyete (umre, hac veya her ikisi) göre niyet etmenin önemi ve hata yapma ihtimaline karşı niyetin Türkçe yapılması gerektiği vurgulanmıştır.

\section{6. İhrâmda Mübâhlar}

Mübâh kelimesi "Yapılması veya terk edilmesi yönünde herhangi bir şer̂̂-dinî yükümlülüğün bulunmadığı fiil ve konum” (Algül vd. 2017, s. 169-170) olarak tanımlanmaktadır. Eserde mübâh görülen davranışlar şöyle sıralanmıştır: ihramlıyken gusl etmek, kirlerini çıkarmaksızın suya girmek, hamamda yıkanmak, elbise yıkamak, yüzük ve kılıç takmak, ipeksiz kuşak ve kemer bağlamak, bir şeyin gölgesinde oturmak, şemsiye tutmak, kokusuz sürme sürünmek, diş çıkarmak (çekmek), çıban sıkmak, kan aldırmak, misvaklanmak, hacamatlanmak, yara bağlamak, yağmurluk örtünmek, aynaya bakmak, hayvan kurban etmek, yastığa baş koymak, elbise giymek, cimcime giymek, yüzü geniş pabuç giymek, kopan tırnağı ayırmak, kıl kopmayacak ve bit telef olmayacak şekilde kaşınmak, balık avlamak, ihramda olmayan avcıların avladıkları avı ele geçirmek ve boş yere terk etmek. Bunların dışında olan davranışların ise yasaklandığı söylenmiştir.

Kadınların erkekler gibi ihrama girdikleri, yalnızca yüzlerine dokunmamak üzere peçe takmaları ve başlarını kapatmaları, elbise giymelerinin caiz olduğu da belirtilmiştir.

\subsection{Cidde'de}

Eserde söylenenlerden, hacı adaylarını Cidde'ye varıldığında onlara yol gösterecek kişilerin vekillerinin karşıladığı anlaşılmaktadır. Bu kısımda, Cidde'de neler yapılması ve nelerden sakınılması gerektiğiyle ilgili cümleler yer almaktadır. Bu satırlar, Cidde'nin hem havası hem de yemekleriyle ilgili bilgiler vermesi bakımından dikkat çekicidir.

Cidde, Suudi Arabistan'n Kızıldeniz kıyısında yer almaktadır. Şehrin önemi ise Hz. Osman zamanında uzak ülkelerden Mekke'ye gelen hacıların karaya ayak bastıkları bir liman şehri olarak kullanılmaya başlanmasından sonra artmıştır (Bilge, 1993, C. 7, s. 524). Eserden de Cidde'nin hac ibadetinde rehberlerin vekilleriyle buluşulan bir yer olduğu, Süveyş'ten ancak vapurla buraya gelinebildiği anlaşılmaktadır.

Havası nemli ve kötü olduğundan Cidde'de yemek yemekten kaçınılması gerektiği dile getirilmiştir. Şehrin meyvelerinin yenmemesi ve yalnızca vücudu kuvvetlendirmek için et suyuyla pişirilmiş çorba içilmesi gerektiği belirtilmiştir. En fazla börek, et ve hurmadan kaçınılması konusunda hacılar uyarılmıştır. Rahatsızlık hissedildiğinde ise vakit kaybetmeden doktora müracaat edilmesi önerilmiştir.

İskenderiye ve Kahire'nin ardından Cidde'deki ziyaret edilecek yerlere de işaret edilmiştir. Birtakım şerefli zâtların burada gömülü olduğu söylenerek Hazret-i Havvâ ile Leylâ ve Mecnûn'un mezarları buna örnek gösterilmiştir. 
Ziyaretten sonra vekillerin yardımıyla deve tedarik edilmesinin 50 kuruş olduğu (CiddeMekke arası) söylenmiş, deveye binmeden önce ise hem deveciye hem vekile bahşiş verilmesi istenmiştir.

Devenin Mekke'ye iki gecede, eşeğin ise bir gecede ulaştığ1; Cidde'deki vekillerin gayet hızlı yürüdüğü; yol deveyle gidilecekse iki hacının bir devenin iki tarafına bindiği; develerin genelde gece yola çıktığı; konaklarda pilav pişirilip yendiği; her hacının pilavın bir kısmını devecisine vermesi gerektiği; deveye uygun şekilde binilmesinin ve hareket edildiği zaman dua ile namazın ihmal edilmemesi gerektiği anlatılmıştır.

\subsection{Mekke'de}

Cidde'den gelen kafilelerin Mekke'de hacılara yol gösterecek olan delil efendiler (rehber) tarafından karşılandığı, rehberlerin ilgilenecekleri hacıları isimleriyle arayıp buldukları ve öncesinde kendilerine Cidde'den haber geldiği söylenmiştir. Anlatılanlara göre, her delil kendi hacısını evine yollamakta ve onlara hürmet gösterip ağırlamaktadır. Bu alt başlıkta ibadetin nasıl yapılması gerektiğinin anlatılmadığı, bunun nedeninin de haccın delil eşliğinde yapılmasıyla ilgili olduğu belirtilmiştir.

Hac dönüşünde kara yolunun tercih edilmesinin kişiye Kudüs'ü ziyaret imkânı da tanıdığı; Medine ile Mekke arasında deve kiralamanın 380 kuruş, Medine'den Yenbu'a 180 kuruş olduğu ve bunun özel bir komisyonca belirlendiği söylenmiştir.

\section{Dil Özellikleri}

Konu "Hac" olduğundan eserde Arapça kelimelerin diğer kelimelere oranı fazladır. Türkçe kelimeler fiiller ve çekim ekleriyle sınırlı kalırken, yapılması istenmeyen davranışların daha çok Türkçe kelimelerle anlatılmaya çalışıldığı görülmektedir. Kurulan cümlelerde Arapça ve Türkçe kelimelerin diğer dillere oranla ön planda olduğu fark edilmektedir. Farsça (Çünkü, hem vb.), Fransızca (bilet, vapur, şimendifer) ve İtalyanca (acente, kumpanya) sözcüklere ise daha az rastlanmaktadır. Eserde en fazla Arapça kelimelerin (hayrlıdır, fâriza, rek'at, namâz, ba'de'l-edâ, îfâ, selâmet vb. ) olduğu, ikinci sırayı da Türkçe sözcüklerin (gitmek, gelmek, bulunmak, eylemek, yoksa, için, deniz, vb.) aldığı söylenebilir. Ayrıca eserde "hatırından çıkarmamak" ve "müşkülâta uğramak" deyimlerinin kullanıldığı dikkat çekmektedir.

Eserin basım amacı hacılara rehberlik etmek olduğundan yazılanların halk tarafindan anlaşı1ır olması önemlidir. Bu doğrultuda Hacılara Yâdigâr'ın anlaşılır bir dille yazıldığı söylenebilir. Zaten İslam dininin etkisiyle halk Arapça ibare ve kelimelere oldukça yakındır. Ayrıca ulaşım imkânlarına demiryolları ve buharlı gemilerin katılmasıyla, doğal olarak bu vasıtalara ait Batı kökenli terminoloji de toplum hayatına girmiştir. Eserde geçen şimendifer, kumpanya, bilet, acente vb. kelimeler bunu göstermektedir.

\section{Sonuç}

Biçim ve içeriği dikkate alındığında eserin, hacılara yardımcı olma amacıyla yazılmış bir el kitabı olduğu söylenebilir. 1890 yılında açılmış olan Ahmed İhsan Matbaası'nda basıldığı kapak sayfasında belirtilen eserin II. Abdülhamid dönemine ait olduğu anlaşılmaktadır. 
Ayrıca fotoğraflar arasında II. Abdülhamit döneminde inşâ edilmiş misafirhaneye ait bir görüntünün yer alması da basımın 1901 yılından sonra yapılmış olabileceğini göstermektedir. Anlatılanlardan Hicaz demiryollarının da henüz faaliyete geçmediği anlaşılmaktadır. Bu sebeple el kitabının basım tarihini 1901-1908 yılları arasına tarihlendirmek mümkündür.

Tanıtımı ve değerlendirmesi yapılan Hacılara Yâdigâr isimli eser hem dönemin hac yolundaki ulaşım imkânlarına hem de hac ibâdeti sırasında yapılması ve yapılmaması gereken davranışlara 1şı tutmaktadır. İskenderiye ve Kâhire'de hangi kutsal mekânların olduğu bilgisini de veren eser, XX. yüzyılın başlarındaki hac güzergâhları ve konaklarını öğrenmemize yardımcı olmaktadır.

Eserde Arapça, Türkçe, Farsça, Fransızca ve İtalyanca sözcüklere yer verilmiştir. Arapça kelime kadrosu ilk sırayı alsa da Türkçe kelimeler azımsanmayacak sayıdadır. Ayrıca eserde hac niyetinin de Türkçe yapılması istenmiştir.

$\mathrm{Bu}$ araştırmayla bir el kitabında hangi bilgilerin yer aldığı, XX. yüzyılın başlarında ulaşım imkânları ile hac anlayışının nasıl olduğu gösterilmeye çalışılmış, dil ve anlatıma dair bazı tespitlerde de bulunulmuştur. Fotoğraflı bir el kitabı örneğinden hareketle yapmış olduğumuz bu değerlendirmenin konu hakkındaki çalışmalara yardımcı olacağını düşünüyoruz. Ayrıca geçmişten bugüne hac el kitapları üzerine yapılacak kapsamlı çalışmalarla da hac yolculuklarının yapılışına dair değişimler daha ayrıntılı olarak görülebilecektir.

\section{Kaynaklar}

Aksoyak, İ. H. (2012). Nâbî'nin Tuhfetü1-Harameyn'inin Edirneli Nâtık'in Tuhfetü'lHaremeyn’ine etkisi: hikâyeler, gelenekler, inanışlar... Milli Folklor, 24 (95), 9-22.

Aksoyak, İ. H. (2020). Nâtık Mehmed Efendi Tuhfe-i Nâtık. İstanbul: KTB.

Algül vd. (2017). İmihal I (iman ve ibadetler). Ankara: İSAM TDV.

Bilge, M. L. (1993). Cidde. DİA. İstanbul: TDV, 7, 523-525.

Bilge, M. L.-Küçükaşçı, M. S. (2013). Yenbu'. DİA. İstanbul: TDV, 43, 421-423.

Buzpinar, Ş. T. (2009). Surre. DİA, İstanbul: TDV, 37, 567-569.

Cengiz, O. (2018). Şam tarihine dair bir bibliyografya denemesi. Türk Akademik Araştırmalar Dergisi Uluslararası Multidisipliner Kongresi. Antalya.

Cosskun, M. (2002). Manzum ve mensur Osmanlı hac seyahatnameleri ve Nâbî'nin Tuhfetü'lHarameyn’i. Ankara: Kültür Bakanlığı Yayınları.

Çavuşoğlu, R. (2019). Hicaz yollarında bir sûfî Mehmed İlhâmî'nin hac seyahatnâmesi. İstanbul: Okurakademi.

Donuk, S. (2017). Servet mahlaslı bir şaire mâl edilen manzum hac seyâhatnâmesi. SUTAD, (41), 13-38. 
Donuk, S. (2017). Sulhî̀nin manzum hac menâzilnâmesi. Divan Edebiyatı Araşstırmaları Dergisi 18, 85-118.

Elmalılı Muhammed Hamdi Yazır. (?) Kur'an-ı Kerim ve Satır Arası Kelime Kelime Okunuşu [Ed. Abdullah Sarıkaya]. Konya, Haktan.

Enverî, H. (1312). Ferheng-i Füşürde-i Sühan. C. 1, Tahran.

Göçer, K. (2016). Osmanlı'dan Cumhuriyet'e ulaşım ve Servet-i Fünûn Dergisi ulaşım bibliyografyası. Bilgi Ekonomisi ve Yönetim Dergisi XI (II), 149-205.

Gül, Â. (2006). Abdurrahman Gubârî'nin hayatı ve eserleri ve Menâsik-i Hac adlı eseri (edisyon kritik). Yüksek Lisans Tezi, Marmara Üniversitesi.

Hacılara Yâdigâr. İBB Atatürk Kitaplığ1 (Bel_Osm_B. 00349).12 s.

Hacılara Yâdigâr. İBB Atatürk Kitaplığı (Alb_000235). 11 s.

Harman, Ö. F. (1996). Hac. DİA, İstanbul: TDV, 14, 382-386.

Hazırbulan, T. (2017). Anonim bir yolculuğun durak noktaları: Menâzil-i Gökbuze ve Menâzili Hersek Ma' Derbend-i Yeni Köy. Çoban Mustafa Paşa ve Kocaeli Tarihi ve Kültürü Sempozyumu IV, Kocaeli, 1957-1973.

http://ataturkkitapligi.ibb.gov.tr/yordambt/yordam.php?sayfaOturumAc

Erişim: 20.07.2020/12:22.

Karal, E. Z. (1988). Osmanlı Tarihi C. VI. Ankara: Türk Tarih Kurumu Basımevi.

Karal, E. Z. (1988). Osmanlı Tarihi C. VIII, Ankara: Türk Tarih Kurumu Basımevi.

Kararmaz, S. (2019). Seyahatnâmeler 1şı̆̆ında Mekke'de Osmanlı mîmârî eserleri. Yüksek Lisans Tezi, Fatih Sultan Mehmet Vakıf Üniversitesi.

Karataş, A. (2003). Türk İslam edebiyatında manzum Menâsik-i Haclar ve Nâlî Mehmed Efendi'nin Menâsik-i Hac adlı eseri. Yüksek Lisans Tezi, Marmara Üniversitesi, İstanbul.

Karataş, A. (2012). Nâlî Mehmed Efendi'nin Menâsik-i Hac manzumeleri. M.Ü. İlahiyat Fakültesi Dergisi, 42 (1), 77-94.

Kiraz, S. (2020). Fethî'nin manzum Menâzil-i Hacc'i. RumeliDE Dil ve Edebiyat Araşstırmaları Dergisi, 18, 310-334.

Kiraz, S. (2020). Konyalı Seyyid Mehmed Efendi'nin manzum Menâsik-i Hacc'1. Külliyat Osmanlı Araştırmaları Dergisi 10, 1-21.

Kiraz, S. (2020). İndî’nin manzum Menâsik-i Hacc’ı (İnceleme-Metin Dizin ve Sözlük). Erzurum: Fenomen.

Koyuncu, F. (2017). Cûdî’nin manzum hac seyahatnâmesi. Littera Turca, 3 (1), 177-219.

Mazığlu, H. (1974). Ahmed Fakih Kitâbu Evsâfi Mesâcidi'ş-Şerîfe. Ankara: Türk Dil Kurumu Yayınlar1.

Muallim Nâcî. (2009). Lügat-i Nâcî. haz. Ahmet Kartal, Ankara: TDK.

Nalçacıgil Çopur, E. (2017). Gubârî̀nin eserlerinde hac ibadeti. Türk İslâm Medeniyeti Akademik Araştırmalar Dergisi, 12 (23), 191-211.

Öğüt, S. (2005). Mîkât. DİA. İstanbul: TDV, 30, 48-49.

Özaydın, A. (1996). İslâm'da Hac. DİA, İstanbul: TDV, 14, 386-389.

Parlatır, İ. (2011). Osmanlı Türkçesi Sözlüğü. Ankara: Yarg1. 
Ramazanoğlu Özcan, N. (2011). Seyyid İbrahim Hanîf'in hayatı, eserleri ve Hâsıl-ı Hacc-ı Şerîf Li-Menâzili'l-Haremeyn adlı eserin incelenmesi. Yüksek Lisans Tezi, Ankara.

Rukanc1, F. ve Anameriç, H. (2009). Türk matbaacılığının önemli isimlerinden Ahmed İhsan (Tokgöz) ve matbaası. Erdem 54, 149-188.

Sarıyıldız, G. (1994). II. Abdülhamid'in fakir hacılar için Mekke'de inşa ettirdiği misafirhâne. Tarih Enstitüsü Dergisi, 14, 121-145.

Sarıyıldız G. ve Kavak A. (2009). Halife II. Abdülhamid'in hac siyaseti Dr. M. Şakir Bey'in Hicaz hatıralar. İstanbul: Timaş.

Süer, F. R. (2015). Umdetü'l-hüccâc. Sivas Belediyesi.

Şemsettin Sâmi. (1996). Kâmûsu'l-a'lâm C.2. Ankara: Kaşgar Neşriyat.

Şemsettin Sâmi. (1996). Kâmûsu'l-a'lâm C.4. Ankara: Kaşgar Neşriyat.

Şemseddin Sami. (2006). Kâmûs-ı Türkî. İstanbul: Çağr1 Yay.

Türkiye Basmaları Toplu Kataloğu Arap Harfli Türkçe Eserler (1729-1928) C. I. 1990. haz.: Müjgan Cunbur-Dursun Kaya. Ankara: Milli Kütüphane Basımevi.

Weyso, M. (2011). Hac yolculuğu metinleri bağlamında 17. yüzyıl halk Osmanlıcası. Yüksek Lisans Tezi, İstanbul Kültür Üniversitesi.

Ziyad, E. (1989). Ahmed İhsan Tokgöz. DİA, İstanbul: TDV, 2: 94-95. 


\section{EK}

\section{METIN}

\section{Hācīlara Yādigār}

Mekke-i mükerreme Medīne-i münevvere Cidde Kuds-i şeríf Şām-1 şeríf ve Șurre-i hümāyūn manz̦araları Bilād-1 mübārekeniñ menāẓır-1 'āliyyesiyle müzeyyen olan şu mecmū‘ a hüccāc-1 kirāma lāzım pek çoḳ ma‘ lūmātı cāmi` dir.

Maṭba`a-1 Ahmed İhsān

\section{Farīiza-i hạacca dā 'ir ba' $̇$ ż-1 ma' lūmāt-1 dīniyye Evvel emrde Mekke'ye mi yoksa Medine'ye mi gitmelidir?}

'Ulemā-yı eslāf bu hușūsda ihtilāf etmişlerdir. Ekābir-i tābi ' inn-i kirāmdan ve ḳudemā-yı fukehā-yı zü̉'liḥtirāmdan 'Alkame ve Esved ve 'Ömer bin Meymūn hażretleri ibtidā Medine-i münevvere’ye gitmek cihetini iltizām eylemişlerdir. İmām-ı Ebū Hanife raḥmetu'llāhi 'aleyh hażretleri hüccāc için aḥsen olan Mekke-i mu'azẓamaya gidip ba' de'l-' arafāt Medine-i münevvereye gitmek iḳtiżā eder buyurmuşlardır. Semerḳandi ḥażretleri fetāvāsında ḳavl-i șānìyi ḳavl-i evvele tercīḥ edip faḳat ḳavl-i evveliñ cevāzına da ḳā ’il olan e 'imme pek çoḳdur diyor.

Zamānımızda hüccācıñ Mekke-i mükerremeden Medīne-i münevvereye beyne'l-‘ 1ydeyn gitmeleri, eger bahren 'avdet edecek iseler, hayrlıdır. Yokssa berren 'avdet eyleyecek iseler ba' de'l-' arafât uggramaları daha hayrlıdır. Evvelleri bahren ' azimet ve berren 'avdet münāsib idi. Faḳat șimdi teymur yolu mevcūd bulundugiundan mezāḥim-i seferiyye hayli ta dîl olunmuşdur. Bu cihetle muvaḥhidīn-i ihlāṣs k ḳarin için arż-1 mübāreke şimendiferle gidip gelmek evlādır.

\section{Hicāz'a Gitmezden Evvel}

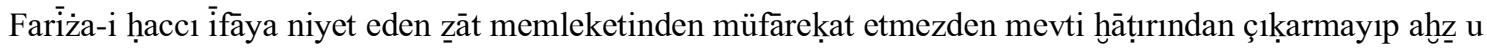

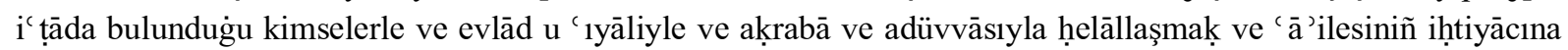
kāfî yiyecek içecek ve giyecek tedārik eylemek vācibdir.

Bundan șoñra sünnet olan iki rek'at nāfile namāzını ba` de'l-edā selāmetle gidip gelmesi için bārgāh-ı șamedāniye ref ${ }^{\natural}$-i niyāz eyleyerek hāanesinden çıḳmalıdır.

\section{Deñiz Tariki}

Ḳıṭ̣ a-i mübāreke-i Hicāz'iyyeye deñiz țarikịinden gitmek isteyen zevāt-1 kirām için evvel emrde İskenderiyye'ye çıḳmaḳ münāsibdir. Çünkü İskenderiyye'ye çıḳılmayıp da țoğrudan țog̉ruya bilet alınıp Süveyş tarikịyle gidilmek istenirse müşkilāta ug̉ranılır. Çünkü oradan Cidde'ye gidecek vapuru günlerce ve hattā ba' żen on beş gün beklemek lāzım gelir. Bu sebeble țog̉rudan țog̉ruya bilet alınmayıp bileti İskenderiyye'ye ḳadar almak ve oradan şimendiferle Süveyş’e gidilmek lāzımdır. Çünkü Süveyş’den her zamān Cidde'ye vapurlar vardır. Ṭog̉rudan țog̉ruya bilet almış bulunan bir hạāi muṭlaḳā biletini aldıg̀ı ḳumpanyanuñ vapurunu beklemege mecbūrdur. Bu da hem vaḳt-i żıyā`ını, hem de masārif-i zā 'ideyi mūcibdir. Ḥāl bu ki țog̉rudan ṭogruya Cidde’ye ḳadar bilet almayıp da İskenderiyye'ye çıkıılır ve oradan teymur yoluyla Süveyş’e gidilirse oradan ilk hareket edece $^{21}$ vapuruñ acentesinden bir bilet alınıp vaḳt gāa 'ib etmeksizin sühūletle Cidde'ye vāṣıl olunur.

İskenderiyye țariḳinde bir fầ 'ide daha vardır. Bir kerre ba` ${ }^{`} \dot{z}-1$ zevāt-1 şerifeniñ ḳabrleri ziyāret olunur; bir de Mıṣr gibi bir ma' mūre-i İslāmiyye'niñ ziyāret ü müşāhedesiyle temettu' olunur.

İskenderiyye'de bulunan başlıca maḳābir-i 'āliyye şu żevāt-1 muhteremeniñdir:

Zü̈'l-ḳarneyn ve Danyāl 'aleyhüme's-selāmıñ ve aṣhāb-1 kirāmdan 'Abdü'r-rezzāḳ raḍiya'llāhu 'anh hażretleriniñ ve Seyyid 'Abdullâh el-mag̉ribi ve țarikẹ-i şāzeliyye a'zasından Ebū'l-'abbās ve Kāfiye șāhịibi İbn-i Ḥācib hạżretleriniñ merāḳıd-1 şerífeleri.

\section{Misrü'l-kāhirde Ziyāretgāhlar}

Bunlardan başḳa (Ḥaseneyn) cāmi '-i şerifinde şehīd-i Kerbelā (İmām-1 Ḥüseyn raḍiya'llāhu 'anh) hażretleriniñ re 's-i sa' ādetleri medfün-1 mevkic -i hürmetdür.

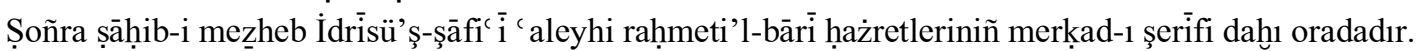

Daha bu zevāt-1 kirāmdan mā'adā pek çok mevāḳı ${ }^{`}$ ü merāḳıdd-1 mübāreke mevcūd olup cümlesiniñ ziyāretlerinden ma`nen ve rūhẹn istifāde ve istifăża olunur.

\section{Mīkāt}

\footnotetext{
${ }^{21} \mathrm{Bu}$ kelime
} 
Hiicāz'a giden kimselerden baḥren 'azīmet eyleyenler Şāb deñizinde Medīne-i münevverenüñ iskelesi olan Yenbu' dan șoñra (Rābig̀) țag̉ı ḥižāsında iḥrāma girerler. Ḳaradan gidenler de Mekke-i mükerreme miḳāăı ḥudūdunda iḥrāma dāḩil olurlar.

İhrāma girecek olanlar mümkin ise gusl ederler; ondan șoñra koltuḳ ve 'avret yerlerini temizlerler; trāşs olurlar; ṭırnaḳlarını keserler. Bundan șoñra iki rek' at (sünnetü'l-iḥrām) namāzını edā eylerler. İlk rek' atında

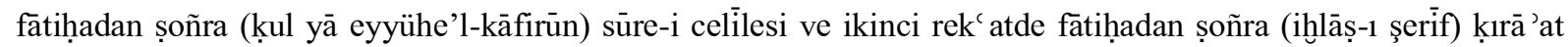
olunur. Ve șoñra elbiseler çıḳarılıp iḥrām giyilir.

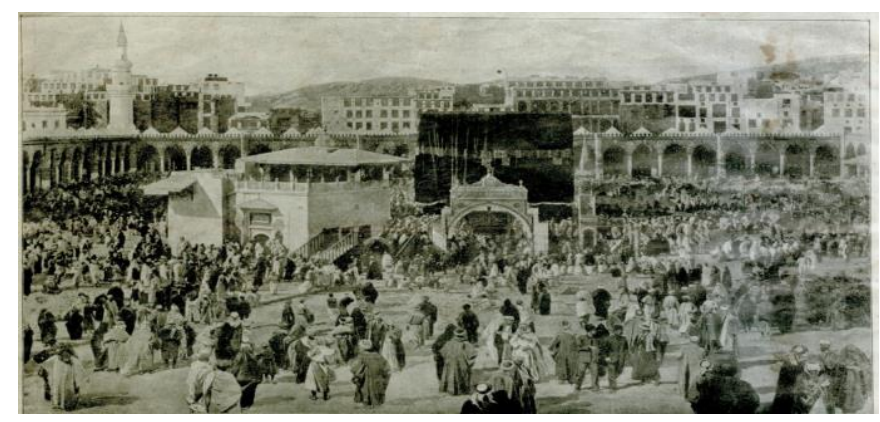

Ka' betu'llāhıñ țavāfı-Ṭavāf-1 Ka' betu'llāh

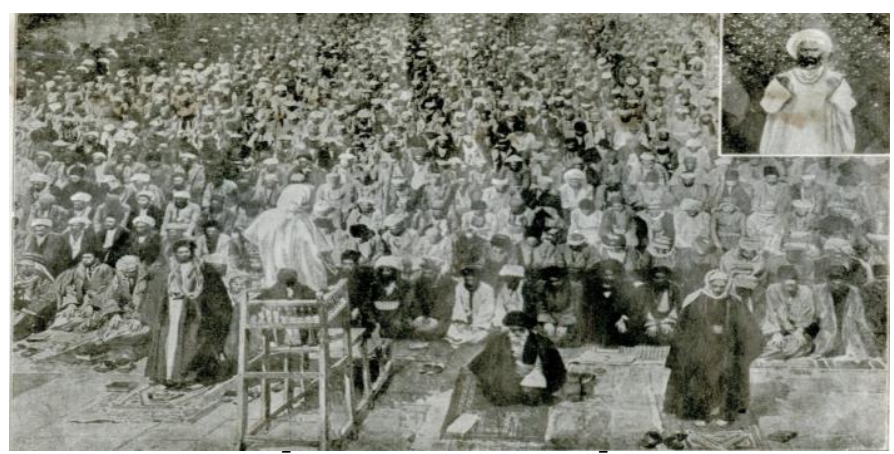

Mekke-i mükerremede hü̈ccāc-1 İrāniyye-El-ḥüccācü'l-İrāniyye fỉ Mekketü'l-mükerreme

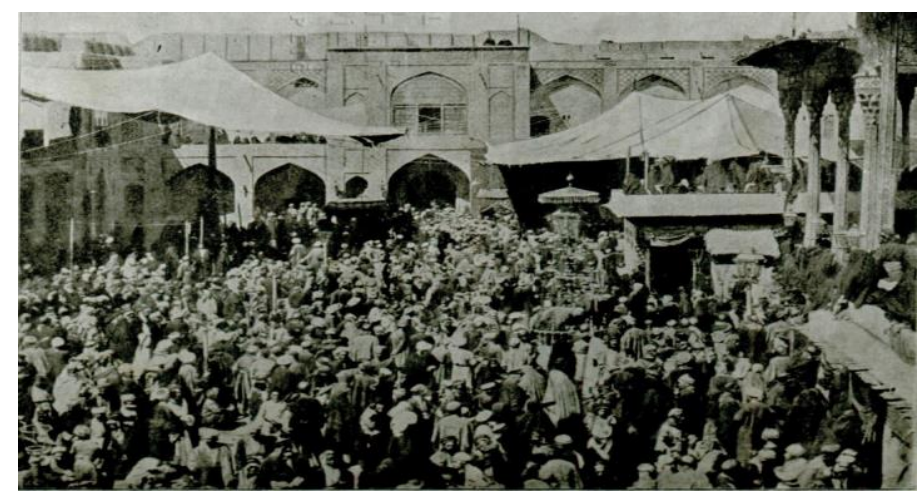

Mekke-i mükerremede hüccāc-El-hüccāc fī Mekketü'l-mükerreme 


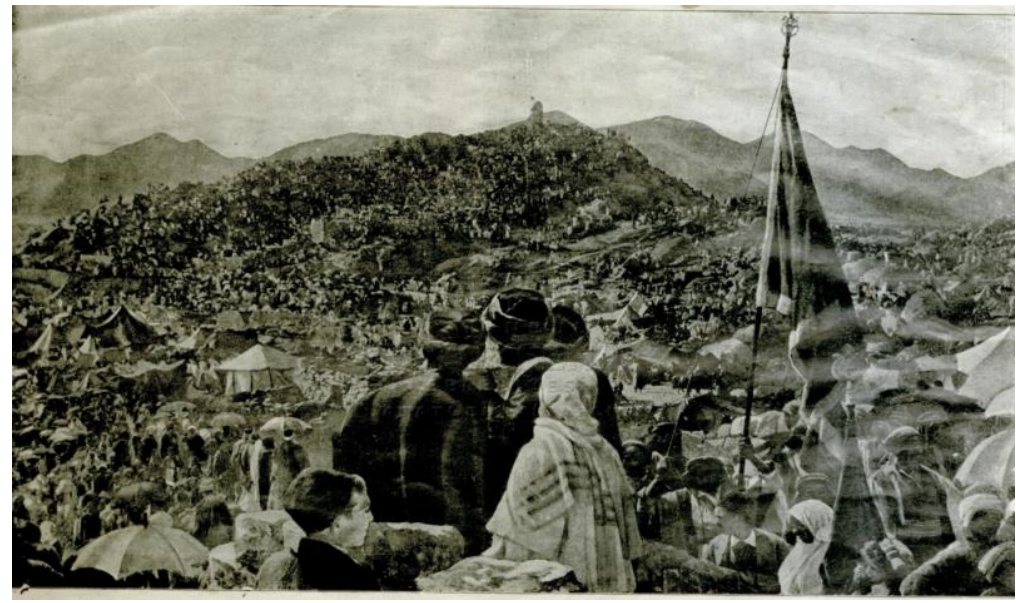

Cebel-i ‘Arafat ve hü̈ccāc-1 müslimīniñ ziyāreti-Cebelü’l-`arafat ve ziyāreti’l-hüuccācü’l-müslimīn

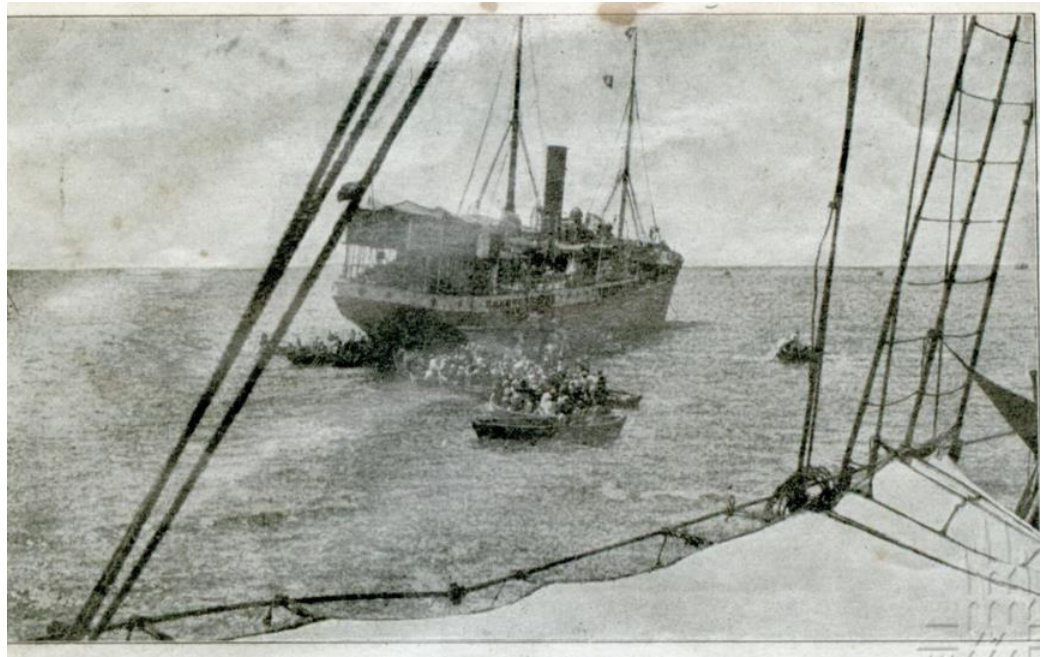

Ḥüccāc-1 müslimīnin Cidde'ye vapurdan hurūcu-Hurūcü'l-hüücācü'l-müslimin mine’l-bābūr fī Cidde

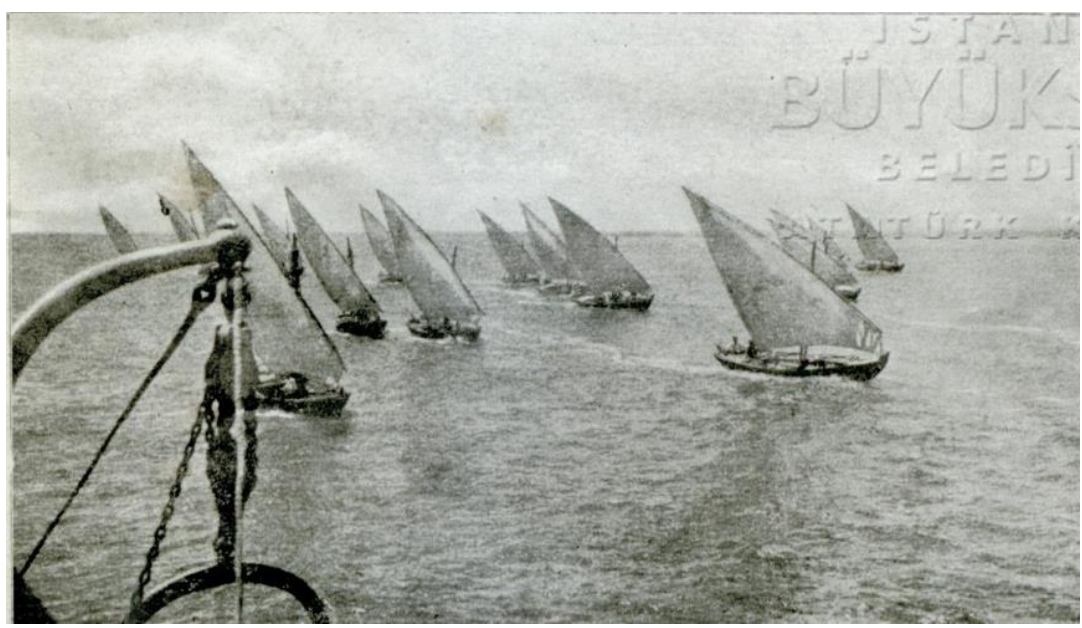

Cidde'de hüccāc kayıklarları-Zenāyịkụi'l-ḥüccāc fỉ Cidde 


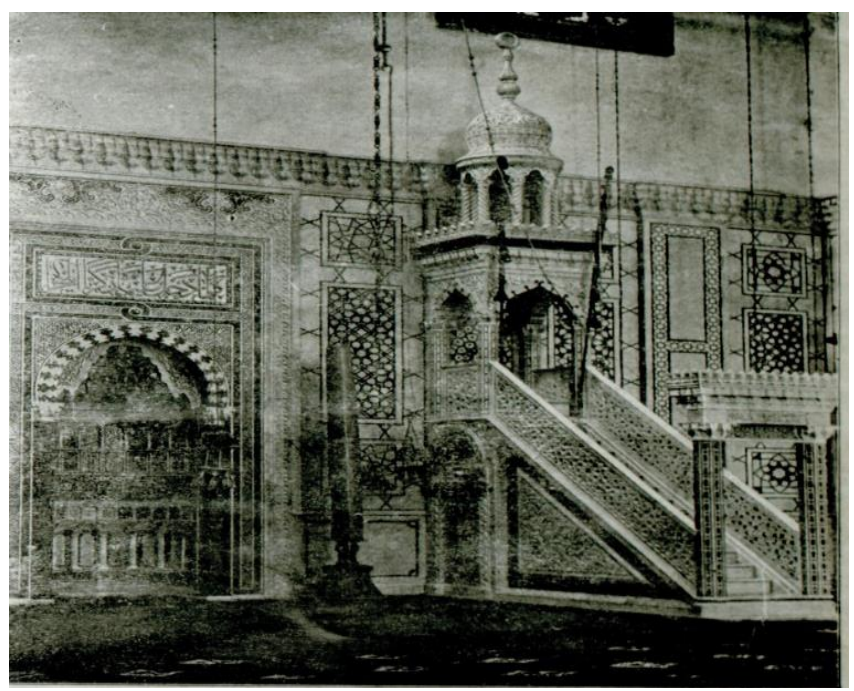

Medīne-i Münevverede bir miḥrāb-Miḥrābü'l-lațî̉f fỉ Medīnetü'l-münevvere

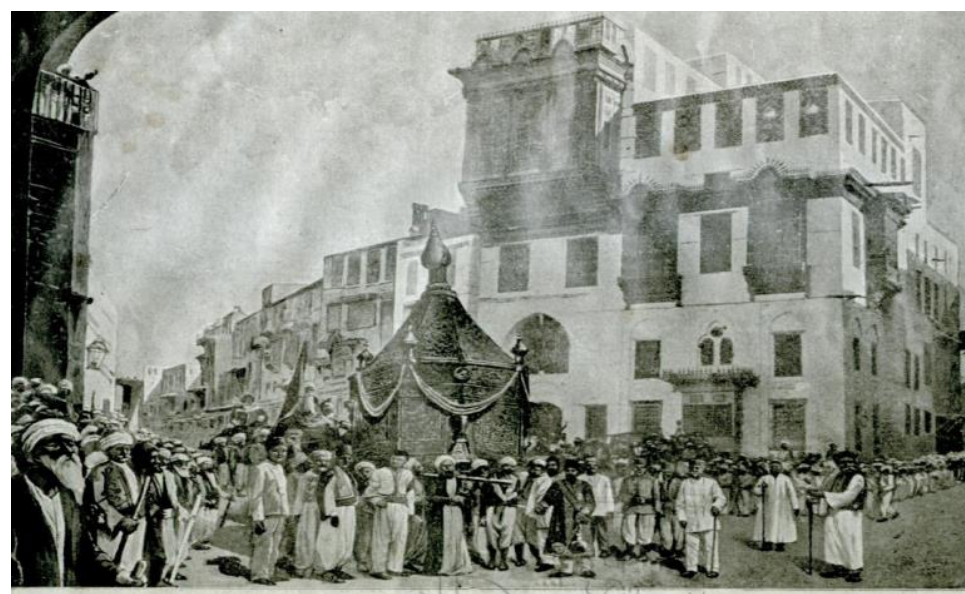

Mekke-i mükerremeye maḥmil-i şerifiñ muvāșalatı-Vușūl-i maḥmilü’ş-şeríf ilā Mekketü'l-mükerreme

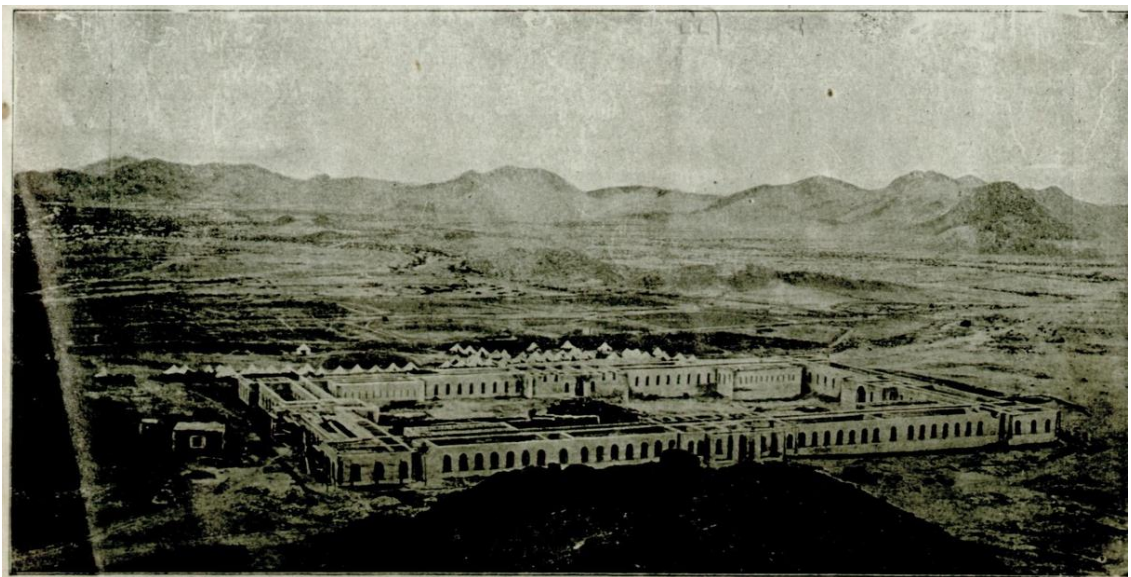

Mekke-i mükerreme civārında misāfirhāne-“misāfirhāne” fī ḳurb-i Mekketü'l-mükerreme 


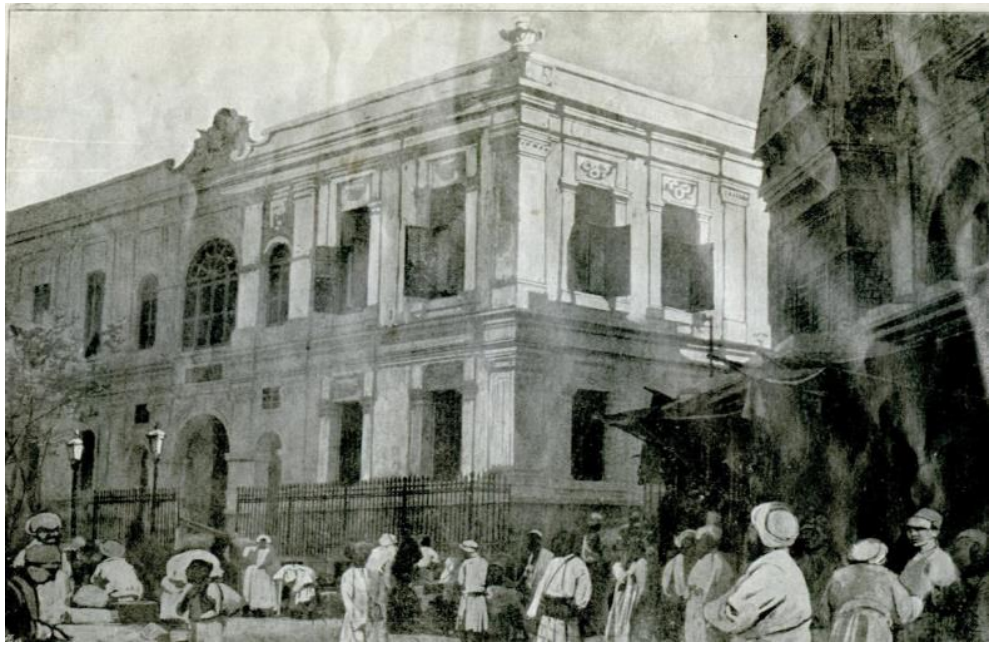

Mekke-i mükerremede dā 'ire-i hükūmet-Dā'iretü'l-ḥükūmet fī Mekketü'l-mükerreme

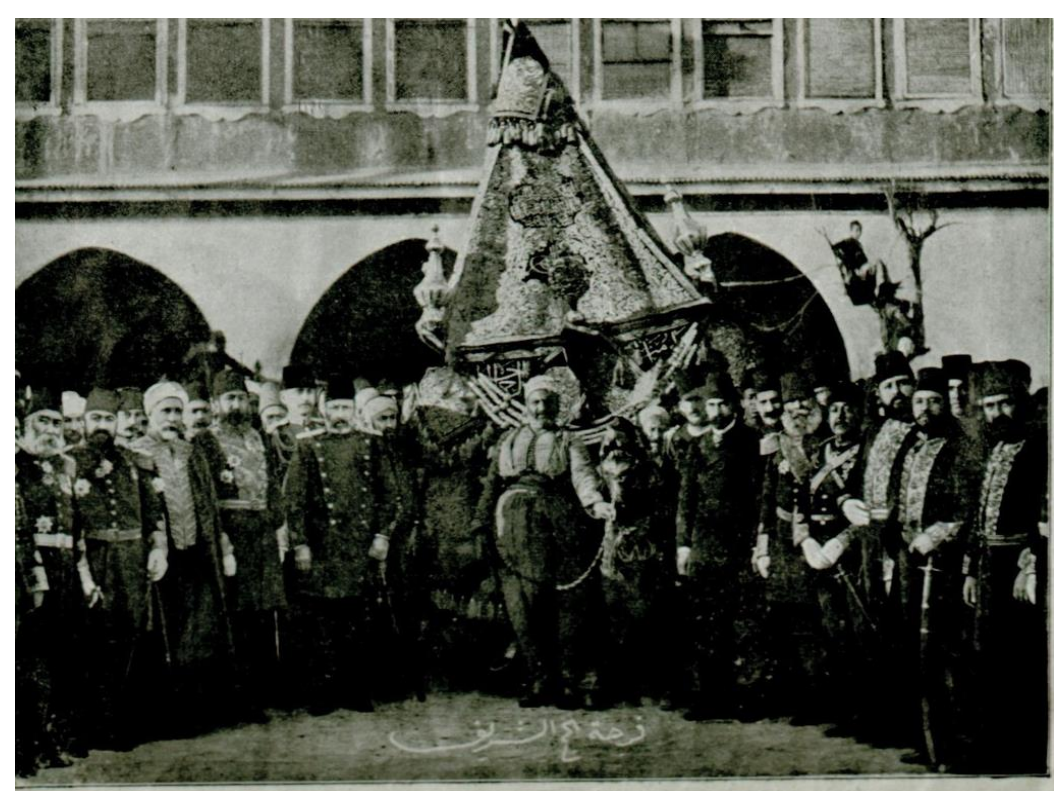

Şām-ı şeriffde maḥmil-i ḥüccāc-Maḥmilü'l-ḥüccāc fi'ş̧-Şām

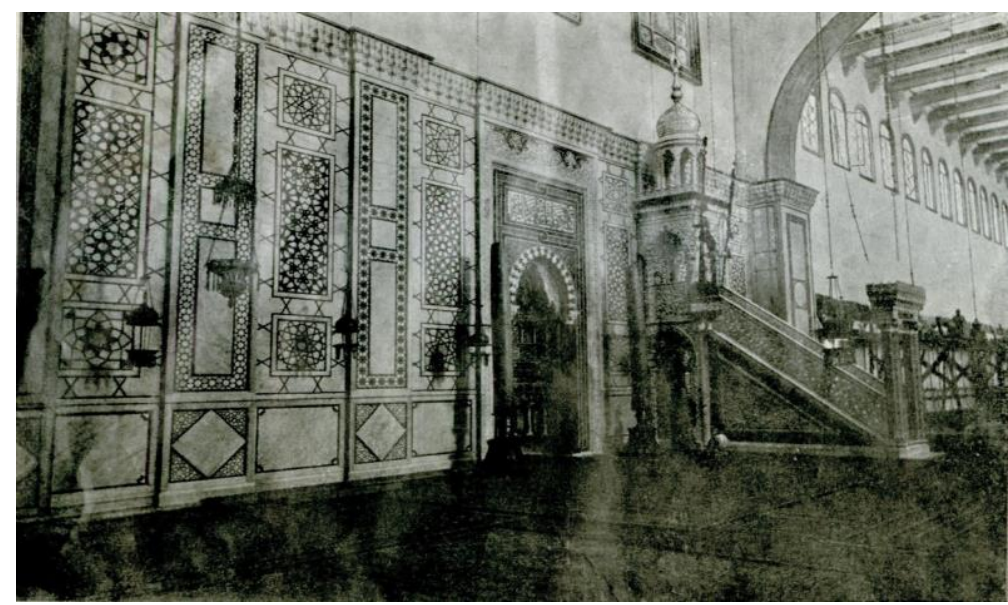

Şām-ı şerifde cāmi` -i Emeviyye derūnunda miḥrāb ciheti-Miḥrāb-ı cāmiü’l-Emevī 


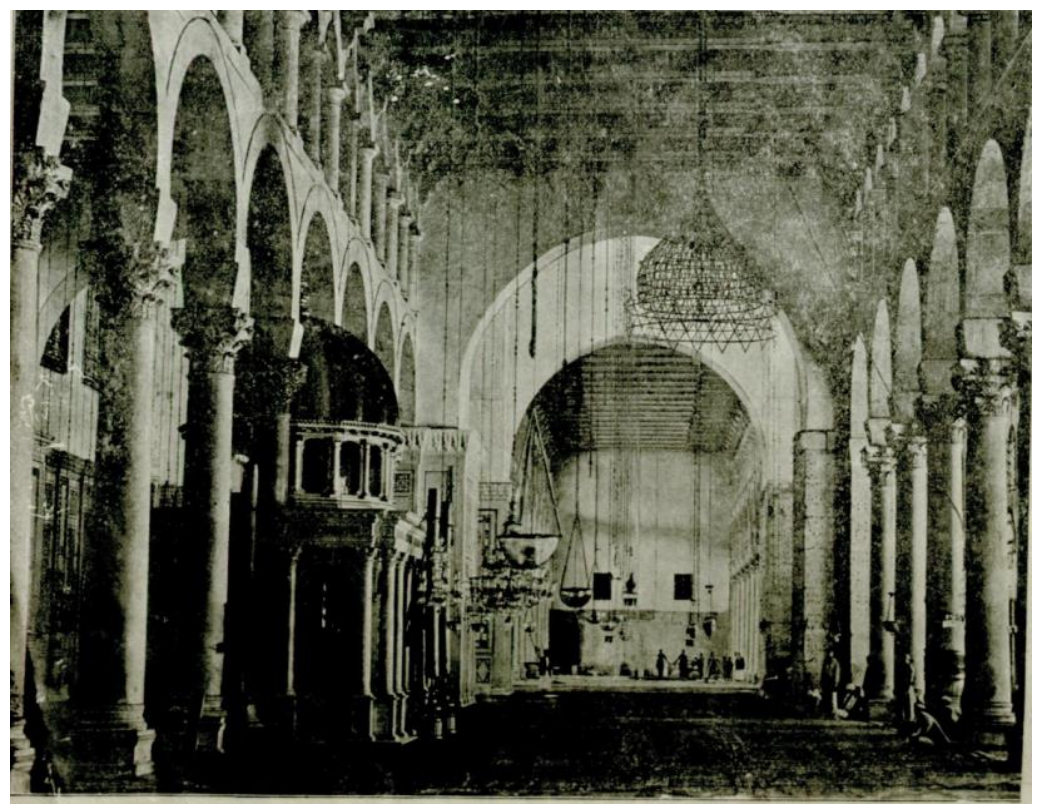

Şām-ı şerîfde cāmi` -i Emevī derūnu-Dāhil-i cāmic ü'l-Emevī fī'ş-Şām

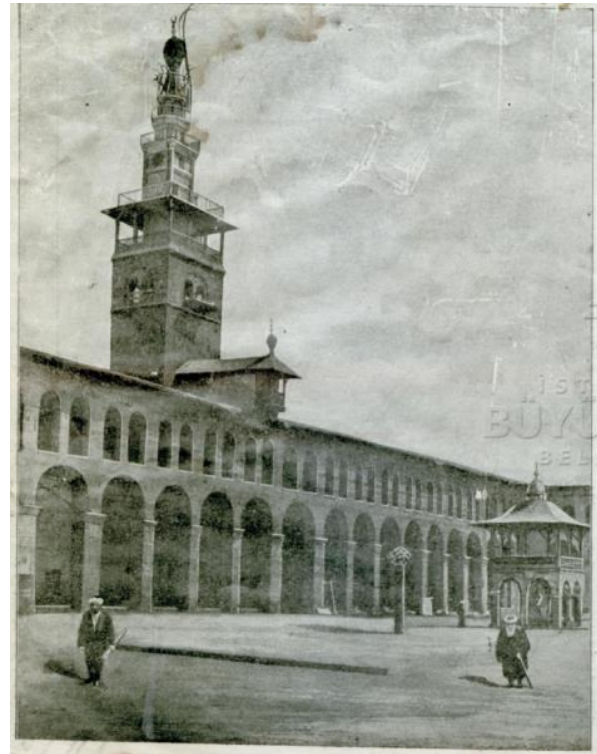

Şām-ı şeriffde cāmic -i Emeviyye ḥavālisiȘaḥn-ı cāmi 'ül-Emevī fi'ş-Şām

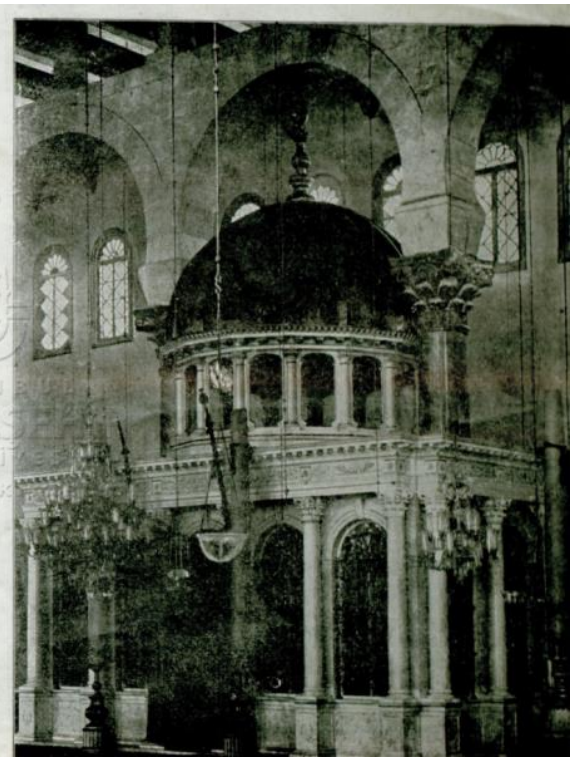

Şām-ı şeriffde ḥażret-i Yaḥyā türbe-i münīfesi -Merḳad-i Seyyid Yaḥyā fi's ş-Şām

ị̣rām iki parça beyāż ḥavludan 'ibāretdir. Bunlara bürünülerek ('Umre) ye niyet olunur. Yalñı ḥacc niyetiyle iḥrāma girenler buña niyet ederler. Eger hem hacc ve hem 'umreye niyet olunursa lisānen her ikisine niyet edilmek lāzımdır. 'Arabca bilmeyenler Türkçe niyet ederlerse ef̣̣aldir. Çünkü 'Arabca'nıñ ma' nāsını bilmeyerek yañlış niyet etmek ị̣timāli vardır.

\section{Iḥ̂āmda Mubāḥlar}

ịhrāmlı iken ġusl etmek, kirlerini çıḳarmaḳsızın șuya girmek, ḥamāmda yıḳanmak, elbise yıḳamaḳ, yüzük ve ḳılınç țaḳmak, ipeksiz ķuşaḳ ve kemer baglamaḳ, bir şey’iñ gölgesinde oṭurmaḳ, şemsiye țutmak ḳoḳusuz, sürme sürünmek, diş çıḳarmaḳ, çıban șıḳmaḳ, ḳan aldırmaḳ, misvāklenmek, hacāmatlanmaḳ, yara bag̉lamaḳ, yag̉murluḳ örtünmek, āyineye baḳmaḳ, ḥayvān żebḥ itmek, yașdıgaa baş ḳoymak, elbise bürünmek, (cimcime) denilen pāpūş veyā na lín giymek, yüzü eñsiz pāpūş giymek, ḳopan tırnaġı ayırmaḳ, ḳıl ḳopmayacaḳ ve kehle telef olmayacaḳ șūretde ḳaşınmaḳ, balıḳ șayd etmek, ihrāmda olmayan șayyādlarıñ șayd etdükleri şikārı tenāvül eylemek ve terki mā-lā-ya'ni etmek mubāḥdır. Bunlarıñ huāricinde olan a' māl ü ef'āliñ cümlesi-gerek ḳașden gerek unudularaḳ 
yapılsın-cināyetdir ve cezā lāzım gelir. Şāyed kehle öldürülürse üçe ḳadar beher kehle için bir ādem țoyurmak, üçden fażla olursa șadaḳa-i fıțr miḳdārında akçe tașadduḳ edilmek lāzımdır sā 'ir-i kūçek ve sinek mișilli ḥayvānāt öldürülürse bir şey' lāzım gelmez.

Ḥaccı veyā ' umreyi ḳablü'l-ekmel mücāma' at edilirse nüsk-i hạcc u ' umre fāsid olur.

Arż-ı ḥaremiñ eşcār u nebātātını ḳaṭ etmek dahi harāmdır. İmām-ı a'ẓam ḥażretlerine göre bunlarıñ ḳıymetlerini tașadduḳ etmek lāzımdır.

Kadınlar dahi erkekler gibi iḥrāma girerler; yalñız yüzlerine țoḳunmamaḳ üzere bir peçe örtmeleri ve başlarını ḳapatmaları, elbise giymeleri cā ’izdir.

\section{Cidde'de}

Cidde'de muvāṣalat olundug̉u zamān her hāāinuñ delīil edinecegi zaātıñ Cidde'ye vekỉil bulunur. Onuñ vāsıțasıyla bir yere inilir. Ġāyet ruṭūbetli ve hevāsı fenā olduguundan münāsebetsiz yemek yemekden ị̣tirāz edilmeli; perhīz olunmalıdır. Yalñız vücūdı kāfīi derece ḳuvvetlendirmek için et șuyuyla pişirilmiş çorba içmeli ve oranıñ mivelerinden șaḳınmalıdır. Hele börek, et, hurma gibi şey'leri çoḳça yemekden gāàet șaḳınmalıdır. Vücūdca biraz rāḥatsızlık hịss olursa der-' aḳab țabỉbe mürāca' at olunmalıdır. Cidde'de birțaḳım zevaāt-1 şerífe medfūndur. Ez-cümle hażżet-i Ḥavvā'nıñ ḳabrleri vardır. Soñra Leylā ile Mecnūn daḩı orada medfūndurlar.

Bunlaruñ ziyāretinden șoñra deve tedārikine baḳmalıdır. Deve vekīl vāsıțasıyla tedārik edilir. Cidde'den Mekke'ye ḳadar beher deveniñ fiyatı ḳıḳ elli guruşdur. Deveye binmezden evvel vekíliñ hidmetine mukāāil kendisine bir mecídiyye ḳadar bir para verilmesi ve deveye bindikden șoñra gerek deve için ve gerek deveci için beş on guuruş șadaḳa nev' inden bahşş̧ verilmesi münāsibdür.

Deve Mekke-i mükerremeye iki gecede ve merkeb bir gecede vāṣ1 olur, oralarıñ vekilleri gaāyet sür atli yürür. Deve ile gidilirse iki hạāi bir deveniñ iki țarafına binerler.

Develeriñ gece yola çıḳması öteden beri mu' tāddır. Gerek yolda ve gerek inip binerken diḳkatli țavranmaḳ lāzımdır. Yolda ḳonaḳ maḥallinde pilav pişirilip yenir. Her ḥācī pişirdigi pilavıñ bir ḳısmını devecisine vermeli ve onuñ da ḳarnını țoyurmalıdur. Bir yere inildigi ve oradan ḥareket edildigi șıralarda du'à oḳumaḳ ve ikişer rek' at namāz ḳılmak ${ }^{22}$ sünnetdir.

\section{Mekke'de}

Cidde'den gelen kāāileleri, delīl efendiler şehriñ ḩāricinde istiḳbāl eylerler ve kendi hạāiları olan zaātları ismleriyle arar bulurlar. Çünkü kendine Cidde'den haber gönderilmişdir. Her delīi ḥācīsını hāanesine yollar ve ḥaḳkında hürmet gösterir.

Artık Mekke'de ikạamet eșnāsında îfā edilecek merāsim ü menāsık-1 hacc delīl efendiniñ ta' rífiyle yapılacaginndan burada i̇żāhından șarf-1 naẓar olundu.

Medīne-i münevvereye 'azīmet edildigi șūretde orada dahı delīl efendileriñ ta' lïmiyle ḥareket olunur. Medīne-i münevvereden 'avdet yā berren şimendiferle veyāhūi Yenbug tarikikiyle baḥrendir.

Berren 'avdet edenler Kuds-i şerifi de ziyāret edebilirler. Medine-i münevvere ile Mekke-i mükerreme arasında beher deveniñ kirāsı (380) guruş̧dur. Medīne'den Yenbū' a ise (180) guruş̧dur. Bu miḳdārlar ḳomisyon-1 mahșususca ḳarārlaşdırılmışdır.

Fiyat 60 paradur

\footnotetext{
22 Kelime "ḳılmaḳı" şeklinde yazılmıştır.
} 


\title{
A Handbook Named Hacilara Yadigar
}

\begin{abstract}
Each religion has it's own sacred places. It is believed that visiting these places will give an eternal life to the person. Therefore, all kinds of difficulties on pilgrimage routes were taken into consideration, and pilgrimage groups went on these journeys to perform their worship at certain times of the year. These problems, which are mostly related to the limited transportation possibilities in the past, have changed with the developing technology today and mostly have been eliminated. Nowadays, pilgrim candidates can make their visits easier.

Mecca, where pilgrimage was performed in Islam, and Madinah, also known as the city of Mohammed, is the most important city that Muslims want to go for centuries by taking all the difficulties. Along with these holy cities, the way other pilgrimages and places are seen determines the way pilgrimage routes are arranged. "Menazil" type works provide important information about the routes followed throughout history. Apart from this, other works that contain the content of the pilgrimage (menasik) shed light on the pilgrimage understanding and journey of the past.

It is seen that among the works related to the pilgrimage, the most studies are done on literary pilgrimage travel books that can be grouped into four groups according to their content and writing purposes (Pilgrimage handbooks, guided pilgrimage travel books, memoirs and reports, literary travel books). Since the pilgrimage handbooks are written to give practical information, it has been realized that there has not been any research on this subject. However, it is possible to come across many elements of history and culture in such works. Although how to make the pilgrimage is in the foreground, these pilgrimage handbooks contain information about routes, places of visit, transportation, etc. In addition, the change of language and expression in these works that appeal to the public according to the periods is another subject that needs to be researched. In this direction, it is aimed to introduce and evaluate the printed work named Hacllara Yadigar in our study.

"Mekka Medina Jidde Jerusalem Capital of Syria and Surre-i Humayun Scenes" was written on the cover of the work named Hacllara Yadigar, which consists of 12 pages, and the pages are divided into 3 columns. By evaluating the form, content, language and expression of this handbook, which also includes photographs, it was tried to observe how the pilgrimage of the period was carried out, what was paid attention to, what means of travel were used, what kind of suggestions were made to pilgrims, and which places were visited along the route. In addition, with this work, by presenting a sample that can be dated to the beginning of the 20th century, the necessity of collective evaluations on the subject has emerged. The course of the changes over the centuries in the preparation of such works is the subject of a separate research and requires collective evaluations about the pilgrimage handbooks.
\end{abstract}

Keywords: Pilgrimage • Handbook • Sacred City and Places 